Q. ZHANG' ${ }^{1}$ J.-J. ZHANG, ${ }^{1}$ and Zh.-M. HAN ${ }^{2}$

\title{
EFFECT OF A Rho KINASE INHIBITOR ON COGNITIVE IMPAIRMENT INDUCED BY CHRONIC CEREBRAL HYPOPERFUSION IN RATS
}

\author{
Received April 12, 2014
}

\begin{abstract}
We examined the efficacy of a Rho kinase inhibitor, Fasudil, on cognitive impairment induced by chronic cerebral hypoperfusion in rats. Thirty-two male adult Sprague-Dawley rats were randomly divided into three groups; treated (T), control (C), and sham-operated (Sh); severe stenosis of the carotid arteries was modeled in the former two groups. During two weeks, $8.35 \mathrm{mg} / \mathrm{kg}$ Fasudil and physiological saline were i.p. applied twice per day in the $\mathrm{T}$ and $\mathrm{C}$ groups, respectively. The Morris water maze test was performed in each group to detect changes in the cognitive function and to observe pathological shifts in hippocampal morphology in rats after eight weeks. The mean escape latency was distinctly shorter $(P<0.01)$, and the percentage of swimming distance within the platform quadrant was significantly greater $(P<0.01)$ in the T group, compared to those in the $\mathrm{C}$ group at the corresponding time points. The rate of carotid artery stenosis in rats demonstrated no statistical difference between the $\mathrm{T}$ and $\mathrm{C}$ groups $(P>0.05)$. Fasudil injections effectively normalized hippocampal pathomorphology in the T group. Thus, the Rho kinase inhibitor obviously ameliorated cognitive impairment induced by chronic cerebral hypoperfusion in rats.
\end{abstract}

Keywords: Rho kinase inhibitor, chronic cerebral hypoperfusion, hippocampus, cognitive impairment, water maze test.

\section{INTRODUCTION}

It was demonstrated that stenosis of the carotid artery not only forms an important risk factor for cerebrovascular diseases, such as transient ischemic attack and cerebral infarction, but is also associated with cognitive impairment [1]. The underlying mechanism might be that ischemia and hypoxia cause significant pathological changes, including excessive production of free radicals, disorders of metabolism of membrane phospholipids in hippocampal neurons, intracellular calcium overload, and release of abundant amounts of excitatory amino acids. Finally, this results in the death of cholinergic neurons in the hippocampus, suppression of activity of choline acetyltransferase, reduced amounts of acetylcholine in the brain, and eventual cognitive impairment in patients [2]. Carotid endarterectomy and carotid angioplasty and stenting demonstrated significant positive therapeutic effects on cognitive impairment [3]. At the same time, carotid angioplasties and stenting may be related to serious complications,

\footnotetext{
${ }^{1}$ Zhongnan Hospital of the Wuhan University, Wuhan, China.

${ }^{2}$ First Clinical Medical College, Three Gorges University, Yichang, China. Correspondence should be addressed to J.-J. Zhang

(e-mail: yaocailicn@163.com).
}

such as vasospasm, carotid artery dissection, acute stent thrombosis, etc. [4]. The incidence of cranial nerve injuries is dramatically higher at carotid endarterectomy than that at carotid angioplasty and stenting [5].

High expression and excessive activation of Rho kinase closely correlate with the initiation and development of many cardiovascular and cerebrovascular diseases. Rho kinase inhibitors provide a new hope for the treatment of diseases of the cardiovascular and nervous system. Shibuya et al. [6] discovered that a Rho kinase inhibitor, Fasudil, possesses an apparent efficacy with respect to cerebral infarction; it might modulate the processes of migration, transformation, infiltration, and phagocytosis of inflammatory cells, suppressing the inflammatory reaction after cerebral ischemia [7]. Huang et al. [8] obtained certain indications that a Rho kinase inhibitor can improve cognitive impairment induced by chronic cerebral ischemia. We utilized the Rho kinase inhibitor to treat cognitive impairment induced by chronic cerebral hypoperfusion in rats and observed its efficacy, so as to provide a new therapy for the prevention and treatment of vascular cognitive impairment. 


\section{METHODS}

Animals. A total of 32 healthy male Sprague-Dawley (SD) rats with the body mass of $250 \pm 25 \mathrm{~g}$ were provided by the Laboratory Animal Centre of the Medical College in the Tongji University. The animals were randomly divided into three groups, treated $(\mathrm{T})$, control (C), and sham-operated (Sh) ones. There were 12 rats in two former groups, and 8 rats in the third group.

Preparation. The rat model of severe carotid artery stenosis was provided by constructing a stenosis in the carotid artery (improved-degree controllable carotid stenosis rat model by Zhou et al. [9]). Under ether inhalation anesthesia a neck midline incision was performed, the skin and muscles were separated, and the common carotid arteries (CCAs) were dissociated bilaterally. Syringe needles (diameter $0.45 \mathrm{~mm}$ ) were tied into a slipknot at $0.5 \mathrm{~cm}$ from bifurcation of the internal and external carotid artery of the proximal part of CCA using \#0 surgical suture soaked by dexamethazone. The end of the surgical suture was remained outside, and the needle was pulled out carefully. Small amounts of DXM penicillin dissolved in saline were dropped at the surgical field. Then the wound was sewed up. In the Sh group, only the CCAs of the rats were dissociated bilaterally. The rate of severe stenosis in the rat model was 70 to $99 \%$.

Two weeks after the model was successfully established, $8.35 \mathrm{mg} / \mathrm{kg}$ Fasudil (Tianjin Chase Sun Pharmaceutical Co., Tianjin, China) suspended in saline was i.p administered in the $\mathrm{T}$ group twice per day for consecutive two weeks. The same volume of physiological saline was injected into rats of the $\mathrm{C}$ group.

Stenosis Rate. Four rats from each group were anesthetized by excessive chloral hydrate and their CCAs were isolated and fixed in $4 \%$ paraformaldehyde. A stenosis site of each CCA was cut out to prepare cross-sectional slices. Three different sections were selected from the stenosis, and the stenosis area of each section was analyzed with a computer image analysis system. Then, the mean values of area the above for each rat were calculated.

Morris Water Maze Behavioral Test. A modified Morris water maze test [10] was performed in rats of each group before and two weeks after the corresponding intervention. (i) Navigation test: On the first day, the rat swam freely for $2 \mathrm{~min}$ to be adapted to the environment. From the second day, the rat was put into water and faced to the pool wall at four starting positions of the water pool. The route and time (escape latency) from putting the rat into water till it found a target transparent platform and climbed onto the latter were monitored and recorded using a computer. Such training was repeated four times with each rat at 8:00 am and at 2:00 pm of each day. If any rat failed to locate the platform in $2 \mathrm{~min}$, the latency was noted as equal to $2 \mathrm{~min}$. The interval between two trainings was $60 \mathrm{sec}$ long, and the total training time was for five days. (ii) Spatial search test: After training, the platform was removed on the sixth day. The rat was put into water and faced to the pool wall at a random starting position. The swimming distance between quadrants and traces of searching for the platform within 2 min were recorded.

Morphological Changes in the Hippocampus. After the water maze test, rats were euthanized by an excessive dose of chloral hydrate. The skull was opened to expose the hippocampus. The latter was isolated and fixed in $4 \%$ paraformaldehyde for $48 \mathrm{~h}$. Fixation was followed by standard dehydration, paraffinization, embedding, hematoxylin staining, and mounting. The sections were observed under a light microscope.

Statistical Analysis. SPSS11.0 statistical software was used to analyze numerical data. The latter are presented below as means \pm s.d. Intergroup comparison of the mean values was performed by the $t$-test, and differences with $P<0.05$ were considered significant.

\section{RESULTS}

Stenosis Rate. No carotid artery stenosis was observed in rats of the $\mathrm{Sh}$ group. The rate of carotid artery stenosis did not significantly decrease after treatment (group T), as compared to that with no treatment (group C, $P>0.05$ ), which is shown in Table 1 and Fig. 1.

Morris Water Maze Test. The average escape latency was markedly longer in the $\mathrm{C}$ group compared with that in the Sh group $(P<0.01)$, but, after Fasudil injections, it was distinctly shorter in the $\mathrm{T}$ group with respect to that in the $\mathrm{C}$ group $(P<0.01)$ (Fig. 2).

The normalized swimming distance toward the platform quadrant was significantly smaller in the $\mathrm{C}$ and $\mathrm{T}$ groups compared with that in the Sh group $(P<0.01)$. In the $\mathrm{T}$ group, it became considerably greater two weeks after treatment than that in the $\mathrm{C}$ group $(P<0.01)$ (Table 2$)$. 
T a b l e 1. Average rates of carotid artery stenosis in differents groups of rats $(\%, x \pm s . d ., n=12)$

Т а б л и ц я 1. Середні значення ступеню стеноза сонної артерії у щурів різних груп

\begin{tabular}{l|c|c}
\multicolumn{1}{c|}{ Group } & Before treatment & After treatment \\
\hline Sham-operated (Sh) & $3.12 \pm 0.08$ & $3.28 \pm 0.12$ \\
Control (C) & $94.09 \pm 2.45 \mathrm{~b}$ & $98.24 \pm 2.67 \mathrm{~b}$ \\
Treated (T) & $95.04 \pm 2.24 \mathrm{~b}$ & $93.20 \pm 2.21 \mathrm{~b} \mathrm{a}$ \\
\hline
\end{tabular}

a: compared with the control group, $P>0.05$; b: compared with the sham-operated group, $P<0.01$.
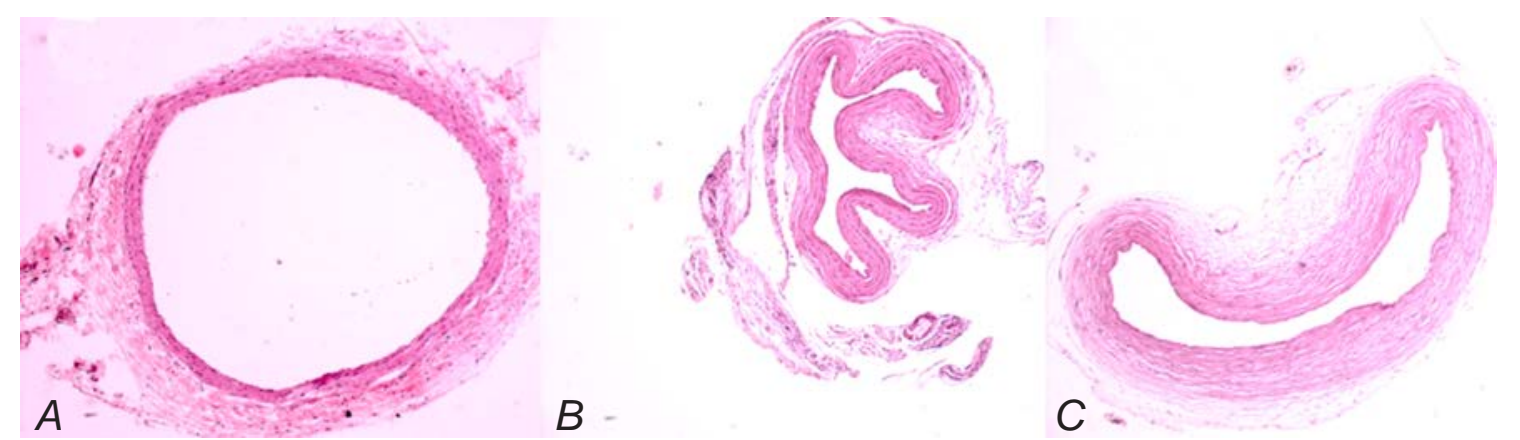

F i g. 1. Cross tissue section of rat arteria carotis communis (HE staining $\times 40$ ). A) sham-operated group; B) control group; C) treated group.

Р и с. 1. Перерізи загальної сонної артерії у щурів псевдооперованої, контрольної та лікованої груп ( $A-C$ відповідно).

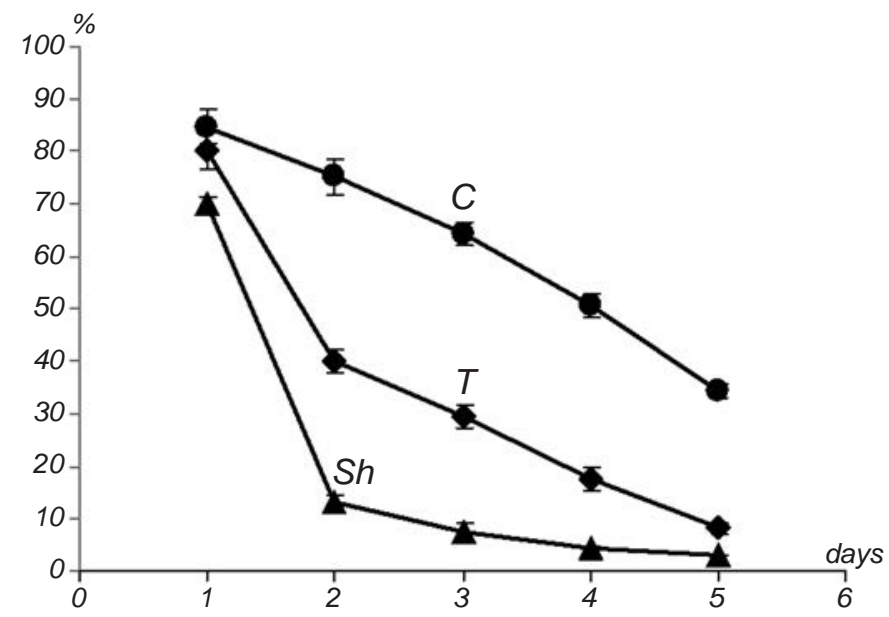

F i g. 2. Changes in the average escape latency after treatment in each group (Sh, C, and T).

Р и с. 2. Зміни середніх значень латентного періоду уникання у різних групах.
The experiment revealed that the normalized swimming distance toward the platform quadrant with respect to the total swimming distance was the biggest in Sh group, while this index in the C group obviously decreased, while the number of entries into the contralateral quadrant increased. After Fasudil treatment, the normalized swimming distance toward the platform quadrant was significantly elevated.

Morphology in the Hippocampus. In The Sh group, rat hippocampal neurons in alignment showed normal morphology, quantity, and distribution; these units had big and round nuclei, as well as clear nucleoli. At the same time rat hippocampal neurons in the $\mathrm{C}$ group were arranged in disorder. Condensed nuclei, their unclear structure, and disappeared nucleoli were observed in a part of the neurons. Rat hippocampal neurons were markedly ameliorated in the $\mathrm{T}$ group compared to those at corresponding time points in the C group (Fig. 3).

T a b l e 2. Normalized swimming distance before and after treatment in each group $(\%, x \pm s . d ., n=12$ in the treated and control groups, $n=8$ in the sham-operated group)

Т а б л и ц я 2. Порівняння нормованих значень відстані плавання у трьох групах перед лікуванням та після нього

\begin{tabular}{l|c|c}
\multicolumn{1}{c|}{ Group } & Before treatment & After treatment \\
\hline Sham-operated (Sh) & $67.75 \pm 2.78$ & $68.56 \pm 2.32$ \\
Control (C) & $36.05 \pm 2.67 \mathrm{a}$ & $30.34 \pm 2.46 \mathrm{a}$ \\
Treated (T) & $39.24 \pm 3.67 \mathrm{~b}$ & $46.68 \pm 3.67 \mathrm{~b}$ \\
\hline
\end{tabular}

a: compared with the control group, $P<0.01$; b: compared with the sham-operated group, $P<0.01$. 


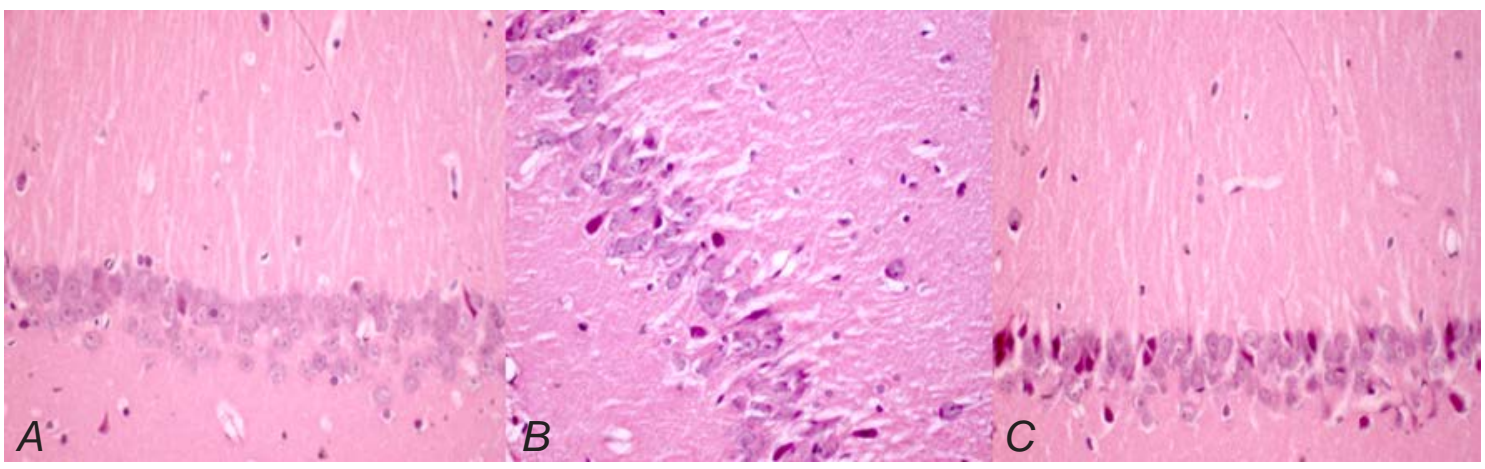

F i g. 3. Photomicrographs of hippocampal slices (HE staining, $\times 40$ ). A) Sham-operated group, the morphology, number, and distribution of hippocampal neurons are normal, with an orderly arrangement. The cell nuclei are large and round, with clear nucleoli. B) Control group, hippocampal neurons are scattered and arranged disorderly. The cell structure is unclear, pyknosis occurred in some cell nuclei, and the nucleoli disappeared. C) Treated group, the morphology, distribution, and arrangement of hippocampal neurons were significantly improved compared with those in the control group.

Р и с. 3. Особливості морфології гіпокампу щурів різних груп.

\section{DISCUSSION}

Vascular cognitive impairment (VCI), first described by Hachinski and Bowler in 1993 [11], is a term to define a large class of cognitive impairment syndromes, from mild cognitive impairment to dementia, induced by cerebrovascular disease-related risk factors (such as hypertension, diabetes, hyperlipidemia, etc.) and obvious (such as cerebral infarction, cerebral hemorrhage, etc.) or not obvious (such as leukoaraiosis and chronic cerebral ischemia) cerebrovascular diseases (including hereditary cerebrovascular ones). Sztriha et al. [12] have confirmed that carotid artery stenosis can cause cognitive impairment as an independent risk factor, which mainly results from thrombosis and hypoperfusion. Hojo et al. [13] have demonstrated that bilateral ligation of the common carotid arteries distinctly damages the cognitive function in rats; this intervention also causes demyelination in the white matter, reactive hyperplasia of glial cells, and neuronal apoptosis, which are similar to pathological changes in the brain of patients with VCI. Our research displayed that the level of cross-sectional area stenosis in rats in the $\mathrm{C}$ group was $92.09 \pm 2.31 \%$, on average.

Chronic cerebral ischemia induced by severe carotid artery stenosis induced significant lengthening of the escape latency in the Morris water maze test, markedly decreased the proportion of the swimming distance in the platform quadrant with respect to the total swimming distance, as well as apparently damaged learning and the memorial function of rats. All these shifts aggravated gradually along with time, indicating that severe carotid artery stenosis led to cognitive impairment and neuronal ischemia in rats determined by pathological changes in their CNS.

Rho-associated kinase (ROCK) is a crucial enzyme involved in a series of cell life phenomena, including adhesion of mitotic cells, cytoskeleton regulation, tumor cell invasion, contraction of muscle cells, etc. [14]. A phosphorylated adducing substrate of ROCK has been observed in the ischemic brain tissue by Yagita et al. [15] using immunohistochemical staining; this indicates that ROCK is active in the ischemized brain [15]. It was demonstrated that activation of ROCK might be significantly involved in cognitive impairment induced by chronic cerebral hypoperfusion. The possible underlying mechanism is the following. Abnormally activated ROCK has adverse effects on the ischemic brain tissue through the following pathways: i) it causes vasospasm [16]; ii) it promotes thrombosis, affects reconstruction and restoration of neuronal networks, leads to oxidative stress, and promotes cell apoptosis [17].

Fasudil is a powerful ROCK inhibitor that strongly reduces the activity of this enzyme [18]. A number of studies have shown that the Rho kinase inhibitor plays an important role in vascular remodeling, improvement of blood circulation, and regulation of the blood pressure. It provides positive effects in the treatment of cardiovascular and cerebrovascular diseases through interaction with vasoactive substances, such as angiotensin II, endothelin-1, etc. [19]. Our results showed that Fasudil considerably ameliorated the impaired cognitive function and alleviated the level of impairment under conditions of chronic cerebral hypoperfusion caused by carotid artery stenosis in rats. This is consistent with the conclusions of previous studies. It was found that 
the Rho kinase inhibitor prevents the development of atherosclerosis. The restenosis after angioplasty shares similar pathological characteristics with atherosclerosis; therefore, the Rho kinase inhibitor is probably also capable of suppressing restenosis $[20,21]$.

The cognitive function was noticeably improved in treated rats. The Rho kinase inhibitor probably can indirectly promote the nitric oxide production, playing a role in antagonizing oxygen free radicals. It can block the metabolism of brain neurotransmitters, prevent certain toxic effects of harmful metabolites, promote neurite outgrowth, and inhibit neuronal apoptosis [22]. However, drug therapy provides only a short-term relief of clinical symptoms, which cannot stop the further development of pathological changes.

Recently, clinical research has shown that stent of the carotid artery can significantly improve negative shifts in cerebrovascular disease and cognitive impairment induced by stenosis of this artery. Problems related to various postoperative complications, such as thrombosis, cerebral ischemia, restenosis, hyperperfusion, and hypoperfusion need to be solved. Especially, restenosis after the stent placement seriously hinders further development of the technique.

Our study demonstrated that there was no significant change in the rate of carotid stenosis in the treated (T) group. Simultaneously, the Morris water maze test suggested that the indicators of rats were markedly different after treatment from those of control group, which indicated that Fasudil could distinctly ameliorate the cognitive impairment induced by chronic cerebral hypoperfusion in rats. In conclusion, Rho kinase inhibitor showed a significant therapeutic effect on cognitive impairment induced by chronic cerebral hypoperfusion.

This study was carried out in strict accordance with the recommendations in the Guide for the Care and Use of Laboratory Animals of the National Institutes of Health. The animal use protocol has been reviewed and approved by the Institutional Animal Care and Use Committee (IACUC) of the First Clinical Medical College.

The authors, Q. Zhang, J.-J. Zhang, and Zh.-M. Han, confirm the absence of conflict of interest concerning the materials or methods used in this study or the findings specified in this paper, and also the absence of conflict between the coauthors.
К. Жан ${ }^{1}$, Дж.-Дж. Жан, ${ }^{1}$ Ж.-М. Хан ${ }^{2}$

ВПЛИВ ІНГІБІТОРА Rһ-КІНАЗИ НА КОГНІТИВНІ УРАЖЕННЯ У ЩУРІВ, ВИКЛИКАНІ ХРОНІЧНОЮ НЕДОСТАТНІСТЮ ПЕРФУЗІЇ МОЗКУ

1 Лікарня Жонгнань при Уханьському університеті (Китай).

${ }^{2}$ Перший клінічний медичний коледж Університету “Три ущелини", Йїчань (Китай).

P е 3 ю м е

Ми досліджували вплив інгібітора Rho-кінази фасудилу на когнітивні ураження, індуковані у щурів хронічною недостатністю перфузії мозку. 32 дорослі самці щурів СпрейгДоулі були рандомізовано поділені на три групи - “ліковану” (T), контрольну (C) та псевдооперовану (Sh); у двох перших групах був модельований важкий стеноз сонних артерій. Протягом двох тижнів щурам груп Т і С внутрішньоочеревинно уводили двічі на день відповідно фасудил у дозі 8.35 мг/кг та фізіологічний розчин. Тварини всіх груп піддавали тесту Морріса у водному лабіринті, щоб виявити зміни когнітивної функції; у цих щурів спостерігали також патологічні зрушення морфології гіпокампа через вісім тижнів. У групі Т середній латентний період початку рухів уникання ставав істотно коротшим $(P<0.01)$, а нормована відстань переміщень у квадранті з платформою була вірогідно більшою $(P<0.01)$, ніж аналогічні показники у відповідних часових інтервалах у групі С. Ступінь стенозу сонних артерій у щурів груп Т та С не демонстрував істотних відмінностей. Ін'єкції фасудилу призводили до істотної нормалізації патоморфологічних зрушень у гіпокампі тварин групи T. Отже, інгібітор Rho-кінази забезпечував явне зменшення уражень когнітивної сфери, індукованих у щурів хронічною гіпоперфузією мозку.

\section{REFERENCES}

1. H. J. Barnett, "Carotid disease and cognitive dysfunction," Ann. Intern. Med., 140, 303-304 (2004).

2. K. Matsumoto and Y. Murakami, "Neuronal damage and decrease of central aeetylcholine level following permanent occlusion of bilateral common carotid arteries in rat," Brain Res., 673, 290-296 (1995).

3. V. Demarin, I. Zavoreo, and V. B. Kes, "Carotid artery disease and cognitive impairment," J. Neurol. Sci., 322, 107-111 (2012).

4. B. J. Kwon, M. H. Han, H. S. Kang, and C. Jung, "Protection filter-related events in extracranial carotid artery stenting: a single-center experience," J. Endovascul. Ther., 13, 711-722 (2006).

5. J. L. Mas, G. Chatellier, B. Beyssen, et al., "EVA-3S Investigators. Endarterectomy versus stenting in patients with symptomatic severe carotid stenosis," N. Engl. J. Med., 355, 1660-1671 (2006).

6. M. Shibuya, S. Hirai, M. Seto, et al., "Effects of fasudil in acute ischemic stroke: results of a prospective placebo- 
controlled double-blind trial," J. Neurol. Sci., 238, 31-39 (2005).

7. X. Sun, M. Minohara, H. Kikuchi, et al., "The selective Rho-kinase inhibitor Fasudil is protective and therapeutic in experimental autoimmune encephalomyelitis," $J$. Neuroimmunol., 180, 126-134 (2006).

8. L. Huang, Z. He, L. Guo, and H. Wang, "Improvement of cognitive deficit and neuronal damage in rats with chronic cerebral ischemia via relative long-term inhibition of Rhokinase," Cell Mol. Neurobiol., 28, 757-768 (2008).

9. Z. Zhou, Y. Zhang, C. Zhu, et al., "Cognitive functions of carotid artery stenosis in the aged rat," Neuroscience, $\mathbf{2 1 9}$, 137-144 (2012).

10. Q. Y. Wu, J. Li, Z. T. Feng, and T. H. Wang, "Bone marrow stromal cells of transgenic mice can improve the cognitive ability of an Alzheimer's disease rat model," Neurosci. Lett., 417, 281-285 (2007).

11. V. C. Hachinski and J.V. Bowler, "Vascular dementia," Neurologym, 43, 2159-2160 (1993).

12. L. K. Sztriha, D. Nemeth, T. Sefcsik, and L. Vecsei, "Carotid stenosis and the cognitive function," J. Neurol. Sci., 283, 3640 (2009).

13. Y. Hojo, T. A. Hattori, T. Enami, et al., "Adult male rat hippocampus synthesizes estradiol from pregnenolone by cytochromes P45017 alpha and P450 aromatase localized in neurons," Proc. Natl. Acad. Sci. USA, 101, 865-870 (2004).

14. B. K. Mueller, H. Mack, and N. Teusch, "Rho kinase, a promising drug target for neurological disorders," Nat. Rev. Drug Discov., 4, 387-398 (2005).

15. Y. Yagita, K. Kitagawa, and T. Sasaki, "Rho-kinase activation in endothelial cells contributes to expansion of infarction after focal cerebral ischemia," J. Neurosci. Res., 85, 2460-2469 (2007).

16. R. M. Pluta, "Delayed cerebral vasospasm and nitric oxide: review, new hypothesis, and proposed treatment," Pharmacol. Ther., 105, 23-56 (2005).

17. S. Chrissobolis and C. G. Sobey, "Recent evidence for an involvement of Rho-kinase in cerebral vascular disease," Stroke, 37, 2174-2180 (2006).

18. Y. Rikitake, H. H. Kim, Z. Huang, et al., "Inhibition of Rho kinase (ROCK) leads to increased cerebral blood flow and stroke protection," Stroke, 36, 2251-2257 (2005).

19. M. J. Koelemay, P. J. Nederkoorn, J. B. Reitsma, and C. B. Majoie, "Systematic review of computed tomographic angiography for assessment of carotid artery disease," Stroke, 35, 2306-2312 (2004).

20. Y. Hirooka and H. Shimokawa, "Therapeutic potential of Rho-kinase inhibitors in cardiovascular diseases," $\mathrm{Am}$. J. Cardiovascul. Drugs, 5, 31-39 (2005).

21. Y. Matsumoto, T. Uwatoku, K. Oi, et al., "Long-term inhibition of Rho-kinase suppresses neointimal formation after stent implantation in porcine coronary arteries: involvement of mutiple mechanisms," Arterioscler. Thromb. Vascul. Biol., 24, 181-186 (2004).

22. S. Satoh, Y. Toshima, I. Ikegaki, et al., "Wide therapeutic time window for fasudil neuroprotection against ischemia-induced delayed neuronal death in gerbils," Brain Res., 1128, 175-180 (2007). 